KHAZANAH MULTIDISIPLIN

VOL 1 NO 12020

https://journal.uinsgd.ac.id/index.php/km

\title{
DIMENSI PEMILU DALAM SISTEM DISTRIK DAN PROPORSIONAL
}

\author{
Diyar Ginanjar'1, Fauziah Hanifah ${ }^{2}$, Uu Nurul Huda ${ }^{3}$ \\ Jurusan Ilmu Hukum Pascasarjana UIN Sunan Gunung Djati Bandung \\ Email : Fhanifah57@gmail.com
}

\begin{abstract}
The electoral system is regulated in statutory regulations containing three main variables, namely voting, electoral district, and electoral formula. As stated in the Election Law, the objective of the electoral system is to exercise people's sovereignty. A provision which is in line with the universal democratic principle of the rulers directs this goal to build legitimacy for a stable and strong government in mobilizing the masses. democratically Election, namely balancing these operational objectives with their use as a means of fighting for the interests of the people through political participation and political socialization.
\end{abstract}

Keywords: Election, Political Participation

\begin{abstract}
ABSTRAK
Dalam peraturan perundang-undangan, pemilu sebagai sistem politik mengandung tiga unsur pokok yakni adalah : penyuaraan, distrik pemilihan dan formulasi pemilihan. Sedangkan dalam peraturan perundang undanga, pemilu mengandung tujuan yaitu untuk melaksanakan kedaulatan rakyat. Disisi lain pemilu menjadi satu ruang dimana rezim mengorientasikan tujuan pemilu pada satu upaya untuk membuat legitimasi masa atas rezim agar kepemimpinan dapat berlangsung secara kuat dan juga stabil. Sehingga secara demokratis dalam upaya penyeimbangan atas tujuan operasional pemilu maka rentetan alur kepemiluan digunakan sebagai alat perjuangan rakyat melalui partisipasi politk.
\end{abstract}

Kata Kunci : Pemilu, Partisipasi Politik

PENDAHULUAN

Pemilihan umum adalah sutau kegiatan politik yang
terjadi di lingkungan sosial. Pemilihan umum merupakan
salah satu alat dan sarana dalam sebuah pelaksanaan
kedaulatan yang mendasar pada demokrasi perwakilan dalam
sebuah negara. Pemilihan umum juga dapat dirumuskan
sebagai mekanisme penyele21ksian dan pendelegasian atau




\section{KHAZANAH MULTIDISIPLIN}

VOL 1 NO 12020

https://journal.uinsgd.ac.id/index.php/km

penyerahan kedaulatan kepada seseorang yang dipercayai melalui perolehan suara dari masyarakat.

Pemilu merupakan serangkaian kegiatan politik yang dilakukan secara demokratis untuk menampung kepentingan masyarakat yang kemudian dirumuskan dalam berbagia bentuk kebijakan (policy). Pemilu yang dilaksanakan diharapkan menjadi representasi dari rakyat selaku pemegang kedaulatan khususnya dalam menentukan pemimpin dalam rangka perwujudan demokrasi Pancasila. ${ }^{1}$ Sebuah sistem pemilihan dapat berupa seperangkat metode transformasi suara pemilih kedalam suatu kursi di sebuah lembaga legislatif atau parlemen.

Berkenaan dengan subjek pemegang kedaulatan, dalam teori hukum dan politik terdapat beberapa ajaran pemegang kekuasaan tertinggi di dalam negara, yaitu : teori kedaulatan Tuhan, teori kedaulatan hukum, teori kedaulatan rakyat dan teori kedaulatan negara. ${ }^{2}$

Sistem pemilu, yang biasanya diatur dalam peraturan perundang-undangan setidak-tidaknya mengandung tiga variabel pokok, yaitu penyuaraan, distrik pemilihan, dan formula pemilihan. Sebagaimana dinyatakan dalam Undang-Undang Pemilu, tujuan dari sistem pemilu adalah melaksanakan kedaulatan rakyat. Suatu ketentuan yang sejalan dengan prinsip demokrasi universal. Akan tetapi dalam pengoperasiannya, penguasa menjuruskan tujuan tersebut

\footnotetext{
1 Marzuki Lubis, Kewenangan Bawaslu/Panwaslu Dalam Pilkada Serentak pada Perspektif Hukum Tata Negara dan Demokrasi di Indonesia Terkait Dengan Revisi Undang-Undang Pilkada.

2 M. Solly Lubis, Ilmu Negara, CV. Mandar Maju, 1990, hal. 40.
} 


\section{KHAZANAH MULTIDISIPLIN}

VOL 1 NO 12020

https://journal.uinsgd.ac.id/index.php/km

untuk membangun legitimasi bagi suatu pemerintahan yang stabil dan kuat dalam memobilisasi massa. Maka pemilu secara demokratis yakni menyeimbangkan tujuan operasional tersebut dengan penggunaannya sebagai alat perjuangan kepentingan rakyat melalui partisipasi politik dan sosialisasi politik, menjadi terabaikan.

Berdasarkan dari uraian latar belakang diatas maka dapat dirumuskan beberapa masalah sebagai berikut :

1. Bagaimana definisi Sistem Distrik atau Plurality and Majority System atau Single Member Constituency?

2. Bagaimana definisi Sistem proporsional (Perwakilan berimbang) ?

\section{METODE PENELITIAN}

Penelitian ini merupakan penelitian deskriptif menggunakan pendekatan kualitatif. Metode kualitatif dianggap menjadi pilihan terbaik ketika mengkaji kehidupan manusia untuk kasus-kasus terbatas, sifatnya kasuistik dan kontekstual namun mendalam (in depth) dan bersifat total atau menyeluruh (holistic), dalam arti tidak mengedepankan pemilahan-pemilahan gejala secara konseptual ke dalam aspek-aspeknya yang eksklusif dan terisolir. Siapa pun yang terlibat dalam bentuk penelitian ini haus menerapkan cara pandang penelitian yang bersifat induktif, berfokus terhadap makna individual dan menerjemahkan kompleksitas sebuah situasi.

Teknik pengumpulan data menggunakan upaya mengumpulan data sekunder. Data sekunder diperoleh dari bahan hukum primer yang difokuskan kepada bahan-bahan studi dokumen atau kepustakaan seperti buku, majalah, dokumen perjanjian internasional (Deklarasi Buenos Aires), makalahmakalah, jurnal, artikel-artikel, surat kabar serta situs-situs internet yang berkaitan dengan objek yang ditulis. Kepustakaan berupa, literatur terkait 
KHAZANAH MULTIDISIPLIN

VOL 1 NO 12020

https://journal.uinsgd.ac.id/index.php/km

seperti naskah ilmiah, media massa, laporan penelitian serta dokumen yang relevan.

\section{HASIL DAN PEMBAHASAN}

\section{Sistem Distrik}

Sistem ini disebut juga sebagai Plurality and Majority System atau Single Member Constituency. Menurut Encyclopedia Britannica, sistem ini adalah cara paling sederhana untuk menentukan hasil Pemilu. Sistem distrik dilaksanakan berbasis tempat daerah pemilihan, hal ini dimaksudkan dengan tidak mendasarkan pada kuantitas penduduk, melainkan pada lokasi yang telah ditetapkan. Setiap distrik memiliki satu wakil dalam parlemen kecuali pada varian block vote dan party block vote. Untuk melaksanakan sistem distrik, maka suatu wilayah negara dibagi dalam sejumlah distrik. Kandidat dalam distrik yang meraih suara tertinggi akan menjadi pemenang. Bagi suarasuara yang diperuntukkan pada calon yang tidak mencapai suara tertinggi akan dianggap hilang dan tidak diperhitungkan walaupun selisih suaranya tipis.

Negara-negara yang menggunakan sistem distrik dalam pemilu yakni:

Hal positif dalam penyelenggaraan sistem distrik antara lain:

1. Mendorong terjadinya integrasi partai politik, hal ini disebabkan karena kursi yang diperebutkan hanya satu;

2. Dapat mengurangi fragmentasi partai dan kecenderungan pendirian partai baru;

3. Mendorong penyederhanaan partai secara alamiah;

4. Wakil yang terpilih akan dikenal karena kecilnya distrik, sehingga hubungan dengan pemilih lebih dekat. Sehingga wakil akan memperjuangkan kepentingan distrik asalnya.

5. Menguntungkan partai besar melalui efek distorsi dari pemilihpemilih lain, sehingga meraih mayoritas. 


\section{KHAZANAH MULTIDISIPLIN \\ VOL 1 NO 12020 \\ https://journal.uinsgd.ac.id/index.php/km}

6. Sistem distrik relative sederhana dan mudah untuk diselenggarakan. Terdapat pula sisi negative dalam penyelenggaraan sistem distrik yakni:

1. Sejauh ini masih dianggap kurang menjawab kepentingan partai kecil ataupun kelompok minor;

2. Sistem distrik dianggap kurang representative;

3. Bagi masyarakat dengan budaya plural, sistem distrik tidak dianggap sebagai sistem yang efektif.

4. Wakil yang terpilih dianggap akan cenderung hanya memperhatikan kepentingan distrik dan konstituennya belaka, daripada kepentingan nasional.

Dalam sistem distrik terdapat lima varian dalam pelaksanaannya yaitu:

1. First past the post

Sistem ini memakai single member district dan pemilihan yang berpusat pada calon, pemenang yakni calon dengan raihan suara terbanyak.

2. Alternative vote

Sistem AV ini memiliki kesamaan dengan sistem FPTP, namun pemilih diberi kebebasan untuk menentukan preferensinya kepada calon yang ada.

3. Two round system

Sistem TRS ini menggunakan putaran kedua sebagai acuan penentuan pemenang, andaikan tidak ada pemenang mayoritas.

4. Block vote

pemilih memiliki kebebasan untuk memilih calon-calon individu yang terdapat dalam daftar calon, tanpa melihat afiliasi dari calon tersebut.

5. Party block vote 
KHAZANAH MULTIDISIPLIN

VOL 1 NO 12020

https://journal.uinsgd.ac.id/index.php/km

Sistem PBV ini memiliki kemiripan dengan BV, yang dijadikan acuan adalah daftar partai-partai yang ada, bukan calon individu.

Negara-negara yang menggunakan sistem distrik ini antara lain Kanada, Amerika Serikat, Inggris dan India.

\section{Sistem Proporsional}

Sistem proporsional (Perwakilan berimbang) yakni sistem pemilihan yang memperhatikan perimbangan jumlah penduduk dengan jumlah kursi di daerah pemilihan. Landasan pemikiran sistem ini yakni hadirnya kesadaran untuk menerjemahkan penyebaran suara pemilih bagi setiap partai menurut proporsi kursi yang ada di legislative. Dalam sistem ini dikenal istilah district magnitude. Dengan menggunakan sistem ini alokasi terbanyak dalam pengisian lembaga legislatif tertumpu pada daerah yang memiliki angka penduduk yang tinggi. Sehingga partai politik yang memenangkan pemilu pada suatu wilayah akan berbanding lurus dengan perolehan suara partai.

Pada sistem proporsional ada sejumlah mekanisme yang digunakan untuk menentukan perolehan kursi. Secara garis besar teknik penghitungan suara dipilah menjadi dua, yaitu teknik kuota dan divisor.

Teknik kuota atau dikenal juga dengan suara sisa terbesar (the largest remainder) terdapat beberapa varian di antaranya varian Hare dan Droop.Ciri umum dari teknik kuota adalah adanya bilangan pembagi pemilih yang tidak tetap, tergantung pada jumlah pemilih. Teknik divisor atau dikenal juga dengan perhitungan rata-rata angka tertinggi (the highest average) muncul berkaitan dengan kelemahan yang ditemukan pada teknik kuota. 
KHAZANAH MULTIDISIPLIN

VOL 1 NO 12020

https://journal.uinsgd.ac.id/index.php/km

Hal positif sistem proporsional yakni:

1. Dianggap lebih representatif.

2. Dianggap lebih demokratis, karena setiap suara dihitung dan tidak ada yang hilang.

3. Memberikan kesempatan bagi partai kecil dan golongan minoritas.

4. Tepat diterapkan bagi negara yang masyarakatnya heterogen dam penduduknya plural.

Hal yang dianggap negative dari sistem proporsional yakni:

1. Kurang mendorong partai-partai untuk lebih berintegrasi

2. Mempermudah fragmantasi partai

3. Memberikan kedudukan yang begitu kuat bagi pimpinan partai melalui sistem daftar karena pimpinan partai menentukan daftar calon

4. Sulit bagi suatu partai untuk meraih mayoritas $(50 \%+$ satu)

Dalam sistem proporsional terdapat dua model dalam pelaksanaannya yaitu:

1. Sistem proporsional tertutup

Pemilih cukup memilih tanda gambar atau lambang partai. Kelebihan sistem ini adalah:

1) mendorong peran partai politik dalam kaderisasi sistem perwakilan.

2) mendorong institusionalisasi partai politik.

Kekurangannya antara lain:

1) pengkondisian mekanisme pencalonan kandidat wakil rakyat yang tertutup.

2) dimungkinkan terjadi oligarki di internal partai.

3) terbukanya ruang politik uang di internal partai dalam bentuk jual beli nomor urut. 
KHAZANAH MULTIDISIPLIN

VOL 1 NO 12020

https://journal.uinsgd.ac.id/index.php/km

2. Sistem Proporsional Terbuka

Pemilih dapat memilih nama atau foto kandidat yang terdapat dalam surat suara. Mekanisme ini menuntut partai politik untuk menyajikan daftar kandidat wakil rakyat untuk dimasukkan ke dalam surat suara dan kandidat yang meraih suara terbanyak terpilih sebagai wakil rakyat. Kelebihan sistem ini antara lain:

1) akan terbangun kedekatan antara pemilih dengan kandidat.

2) pemilih dapat memberikan suaranya secara langsung kepada kandidat yang disukai sesuai preferensinya.

3) memperkuat partisipasi dan control public sehingga mendorong peningkatan kinerja partai dan parlemen.

4) dinamika internal partai tinggi, sehingga mendorong mesin partai bergerak efektif, caleg popular dapat mendongkrak elektabilitas partai.

Kekurangan dari sistem ini antara lain:

1) ada potensi mereduksi peran partai politik secara institusi

2) kemungkinan terciptanya kontestasi antar kandidat di internal partai.

3) membuka ruang politik uang yang massif.

Negara-negara yang menggunakan sistem distrik ini antara lain Rusia, Spanyol, Swedia, Swiss, Belgia, Denmark, Italia, dan Yunani. 


\section{KHAZANAH MULTIDISIPLIN \\ VOL 1 NO 12020 \\ https://journal.uinsgd.ac.id/index.php/km}

\section{SIMPULAN}

1. Sistem ini disebut juga sebagai Plurality and Majority System atau Single Member Constituency. Menurut Encyclopedia Britannica, sistem ini adalah cara paling sederhana untuk menentukan hasil Pemilu. Sistem distrik dilaksanakan berbasis tempat daerah pemilihan, hal ini dimaksudkan dengan tidak mendasarkan pada kuantitas penduduk, melainkan pada lokasi yang telah ditetapkan.

2. Sistem proporsional (Perwakilan berimbang) yakni sistem pemilihan yang memperhatikan rasio pertumbuhan serta kepadatan penduduk yang di sesuaikan denga jumlah perwakilan politik. Hal ini muncul sebagai kesadaran untuk membaca rasio masyarakat dengan perwakilan menurut proporsi lembaga legislatif.

Kompleksitas situasi politik nasional terus berubah dan terus berkembang seiring berjalannya. Maka dari itu kami mengharapkan dengan berkembangnya situasi politik dan polemik yang tak berujung menjadi satu instrument untuk menciptakan pembangunan nasional yang berkualitas karena terlahir dari konflik dan pertarungan ide politik yang massif. Konflik yang berkualitas akan menciptakan tatanan masyarakat yang berkualitas pula, dalam konteks politik nasional harapan tersebut bertumpu pada penciptaan stabilitas politik tapi bukan dalam ruang keterpimpinan belaka serta penciptaan kualitas pembangunan yang berperadaban. Karena dalam pembangunan nasional tidak hanya menjadi tugas aparatur pemerintahan dan partai politik saja, tugas terpenting ada pada akar masyarakat sipil sebagai akar rumput perubahan nasional. 


\section{KHAZANAH MULTIDISIPLIN}

VOL 1 NO 12020

https://journal.uinsgd.ac.id/index.php/km

\section{DAFTAR PUSTAKA}

Budiarjo, Mariam, 2008, Dasar-Dasar Ilmu Politik, Jakarta : PT. Gramedia Pustaka Utama. Prihatmoko, dkk. 2008. Menang Pemilu ditengah oligarki Partai, Yogyakarta : Pustaka Pelajar.

M. Solly Lubis, Ilmu Negara, CV. Mandar Maju, 1990,

Marzuki Lubis, Kewenangan Bawaslu/Panwaslu Dalam Pilkada Serentak pada Perspektif Hukum Tata Negara dan Demokrasi di Indonesia Terkait Dengan Revisi Undang-Undang Pilkada. 